\title{
CONDITIONS IN STOVE MANUFACTURING
}

\author{
By William J. Myers, \\ President, National Association of Stove Manufacturers, \\ New York City.
}

For a better discussion and understanding of present business conditions in this industry, some reference for the purpose of comparison should be made to the recent past when business in nearly all lines was on a high plane of prosperity.

When the financial panic swept over this country in October, 1907, the stove manufacturers had hardly completed the delivery to the retail trade of the stoves which had been ordered for the early fall demand. Such orders under the stimulus of the prosperity of the three or four preceding years, which seemed likely of continuance, had been liberally made, and manufacturers realized the largest output for any October in the history of the industry. The belief so general at first that the panic was but an unpleasant financial gust soon to pass over, with only a few blow-downs chiefly among stock speculators and so-called frenzied financiers, was shared by the stove interests, and hence manufacturers did not suffer countermands of orders as would have been the case had the crash precipitated itself two months earlier. They did suffer in the month of December, when business fell off alarmingly, but the year remained a record one for large sales. The full force of the business depression, however, was felt in 1908 , and was early indicated when salesmen were sent out for new business.

The element of weather is one that plays an important part in the stove business and often operates to offset general business depression. Two-thirds of the annual business in stoves is transacted by manufacturers and wholesalers in the last four months of the calendar year, and with good, crisp fall weather and a cold winter, stove manufacturers and the dealers as well, except from delayed payments and losses from bad debts, do not feel the full force of bad times. In the fall of 1908, however, Jack Frost did not come to the rescue of those interested in the stove business, and they felt the depression equally with those in many other lines. 
Stove manufacturers for the most part are broad-minded men and harbor few jealousies. A high degree of harmony and a wide spirit of co-operation exist among them. Many are members of the National Association of Stove Manufacturers, with its principal office located in Chicago, and nearly every devotee of the industry is a member of one or more of the nine constituent associations, covering the various districts into which the United States is divided. There is no such thing as a trust, holding company or consolidation of interests in the stove industry, but the manufacturers are well organized for their mutual welfare and the correction of abuses that often creep in and tend toward the destruction of a great industry, preventing the concentration of the mind upon ideas for its betterment, which in this branch means the creation of more artistic designs, new serviceable attachments, increased cooking conveniences and the development of improved methods in foundry practice. It cannot be said, however, that great advancement has been made in the application of machinery in stove production, the molding machine having so far been developed for but limited use and economy.

It is due to the splendid organization of the stove manufacturers that but few failures were recorded among them during 1908, notwithstanding that the business fell off in some sections thirty-five per cent, with an average decline in all of fully twentyfive per cent. The stove industry is one that employs capital to the extent of about $\$ 60,000,000$, with an annual output of about the same amount, hence requiring one dollar of capital for every dollar of sales. This is due to the necessity of manufacturing and carrying for months numbers of stoves to meet the demand in fall and winter, which often becomes extra large and urgent, and to the further fact that a very large percentage of the cost of stoves to manufacturers is the wages of workmen which are generally paid weekly.

Upwards of fifteen thousand hands are employed in the stove shops and factories in the United States, and over three million pieces of goods are distributed annually. Without organization and perfect machinery for the gathering and dissemination of information as to the effects of the general business depression upon the demand for stoves in all sections, ignorance of the facts and fear would have prompted price cutting and reprisals with 
complete demoralization as the result. The trade suffered loss of profits through reduced sales and continued high cost of distribution, but was spared the inroading of its capital by added losses through slaughter of prices.

Coincidently with the falling off in domestic sales was the decline in the foreign demand. Almost as soon and almost in the same ratio the demand for stoves from foreign countries declined. The export of stoves does not make a large item of our foreign commerce, owing to the fact that it is almost entirely confined to types designed for cooking. Comparatively few American heating stoves are shipped abroad, and those that are shipped go mainly to China, Japan, Chile and Argentina; Germany and France supplying the larger European demand. While heating stoves form a large part of the product of American stove foundries, the world's markets are little open to them. Our export possibilities are confined to cooking stoves, the use of which is limited in many of the warm countries which are good customers for other lines of American manufacture.

It was stated during the recent panic that the United States had become so large a factor in the world's commerce, and New York City so much of a financial center, that the effects of our panic were felt around the world. It may be due to this fact that the reduction of the export demand in rgo 8 kept such regular step with the domestic decline, but it was certainly due in many cases to special causes in the countries themselves. For instance, we could not have been responsible for the depression in South Africa, which had continued for nearly four years and reached its climax in 1908, and was due to the natural reaction of overspeculation after the Boer war, and the vast quantities of canned provisions and war supplies sold there by the British government at its close.

Orders from China had not been liberal since the boycott placed on American goods; the Japanese were not overanxious to buy American stoves while the excitement continued over the California incident; Chile was having a controversy with Peru; and Cuba was under the military control of the United States and her people were full of jealousy and more or less of hatred for us. For two or three years prior to 1908 the demand from some of these countries had been reduced, but was not felt in the midst of our phenomenal home prosperity. It was unfortunate, however, that untoward cir- 
cumstances continued during the year of our business decline. In Mexico, where merchants and business men had been enjoying a season of prosperity second only to that enjoyed here, the American panic did cause much distress, and much capital of Americans held in banks in Mexico for investment or for use in enterprises there was hurriedly withdrawn to cover sudden obligations in the states. Australia and New Zealand, for thirty-five years a profitable field for American stoves, have been almost entirely yielded up to Great Britain on account of low prices impossible for American manufacturers to compete against.

The export demand for stoves is often a fluctuating one and increases but slightly even when normal conditions prevail, for, in proportion as the demand increases in certain parts of the world, competition grows or local makes supply part of the additional demand. In several places in South America local-made wroughtiron or sheet-steel cooking stoves are sold in considerable numbers, while German and French competition is extremely keen, and more favorable terms are offered than American manufacturers seem willing to make. Since the Japanese-Russian war, factories have been established in Japan and American stoves imitated. The same is likewise true of New Zealand, where local foundries have been established within the last few years.

Notwithstanding all this, it can be said that the export revival as shown this year is greater than the domestic. With the opening of the year the demand from South Africa was distinctly an improvement over what it was for four years previous, and has thus far been maintained throughout the year. It would seem that they have passed through their period of reconstruction and, with good crops, have returned to prosperous conditions. But little recovery is realized in the Mexican demand. Capital has not been replaced, and floods, earthquakes and insurrections have further hindered the return of prosperous conditions. Some increase in demand is noted from Argentina, owing partly to the steady advancement being made in that country, the increase of population and the influence of the forthcoming transportation exposition to be held next year. But the demand would be greater in all South American countries if our people had followed up the advantage opened to them by the passage of the United States fleet around the continent and ex-Secretary Root's visit. 
The direct effect of the tariff on the stove industry is almost a negligible quantity. The indirect effects are considerable, because whatever affects adversely the production of other American manufacturers and shortens factory operations reduces the purchasing power of the wage earners, and the stove is about the first among the articles of household utility that in bad times the workman aims to repair instead of appropriating money for a new one. Foreign made stoves, however, cannot obtain a foothold in this country in competition with our own goods. They are heavier, clumsier, unsuited to our needs, and with all packing, shipping and commission charges added to the initial cost, their price would be too high.

It is not a fact that underselling us secures to our foreign competitors an advantage in the disputed fields of Central and South America so much as the willingness of the Europeans and British to make long terms and bestow more attention upon the packing requirements. In nearly all countries south of us the American stoves are preferred for their lightness of weight, style and many conveniences, but much complaint is heard of the inattention of American manufacturers to detail and of their unwillingness to extend credits. We are no doubt largely to blame that our exports amount to only about two per cent of the total value of our output of stoves, amounting in 1908 to only a little over one million dollars.

While not directly affected by the tariff, stove manufacturers, realized how seriously tariff discussion interrupts general business, and their national association sent delegates to the National Tariff Commission Convention in Indianapolis in February last, and aided the movement to petition Congess for the appointment of a commission of experts and business men of probity to gather tariff facts for the use of Congress and the Executive, so that in future an intelligent and scientific tariff might be constructed.

Save in an industrial panic such as overspread this country in r893, when the harmful effects endure longer and business men weary in waiting for the tide to turn, it is seldom that the stove trade experiences two poor fall seasons in succession; and the indications are that the approaching season will not be an exception to that rule. The demand this year, despite the tariff agitation, has increased. For the first eight months of 1908 sales fell off twenty per cent on the average, while for the same period this year they 
have increased twenty per cent. This by no means signifies a full recovery of 1907 volume, as the increase is based on a much smaller total than the decline, but it has been steady and carries hope and confidence of continuance.

The autumn demand is expected to be very satisfactory from the fact above stated that two bad seasons in this line rarely come together. The expectation seems especially founded this year, when improvement in so many other lines is noted. Increased stove sales should be made if the earning power of the people has been and is being increased over last year, because many old stoves that were patched to last out the winter of a year ago must go to the junkman this fall. The natural increase in population, moreover, and return of many of the emigrants who left our shores in 1907 and 1908 will furnish a good extra demand. The increase this year would need to be nearly thirty-three and one-third per cent to equal stove sales in 1907 , and this is too much to expect so soon. The volume will hardly equal that of 1906 , but will probably run close to that of rgo5, a very good year in the stove trade.

The people's savings were much larger when the reverse came in 1907 than they were at the previous panic and they did not run so heavily in debt during the period of idleness. Aside from the reduced purchasing power of wage earners, the business horizon is almost clear of obstacles to the spending of money for all the ordinary wants of the people, and the more liberal purchasing of luxuries by those in more comfortable circumstances. The business skies are clear, the air is not foggy with complex economic or political problems to clog the mind, check ambition or block enterprise; the tariff is settled, building is improved, crops are abundant, even though not of bumper proportions; there exist no serious international controversies; no presidential election stares us in the face for three years to come. The people have confidence in the good judgment and fair-mindedness of President Taft; there are no alarming labor troubles to disturb the country; stocks remain high, reflecting good times, and unless the weather proves very unpropitious for stove traffic, stove manufacturers will have reason to feel satisfied with the year's business. It ought certainly to be a twenty per cent increase over that of 1908 , with every prospect, barring the intervention of war, pestilence or great convulsions of nature, of greater improvement in the year to come. 